\title{
Longitudinal Study on Reproductive and Productive Performances of Smallholder Crossbred Dairy Cattle in and Around Wolaita Sodo, Snnpr, Ethiopia
}

\section{Mandefot Meaza*}

School of Veterinary Medicine, Wolaita Sodo University, Ethiopia

\begin{abstract}
This study was conducted to assess the reproductive and productive performances of smallholder crossbred dairy farms in Wolaita Sodo town of Southern Ethiopia. Twelve smallholder crossbred dairy cattle farms were studied longitudinally for two years. Almost all of the farms were intensively managed and basic farm management practices with acceptable animal health and artificial insemination services from the nearby animal health care organization had been practiced. However, professional assisted pregnancy diagnosis and farm animal record keeping were less experienced. The overall means and standard error $(\mathrm{M} \pm \mathrm{SE})$ of age at first calving, calving interval, calving to conception interval and number of services per conception were $37.5 \pm 0.6$ months, $518.0 \pm 22.5$ days, $253.9 \pm 22.6$ days and $2.1 \pm 0.2$, respectively. Among independent variables considered in the study only farm size had significant influence on age at first calving $(P<0.05)$. The mean of average daily milk yield, lactation length and lactation milk yield were estimated to be $8.32 \pm 0.6$ liter, $423.79 \pm 16$ days and $3534.16 \pm 311 \mathrm{~kg} / \mathrm{cow}$, respectively. Generally, the observed reproductive and productive indices showed poor performances which are below the recommendations of crossbred smallholder dairy farming in the tropics. Several reproductive health problems were prevalent in the study area with mastitis being the most prevalent. Accordingly, training on managemental aspects of dairy farming and extension services to enhance production and reproduction is needed. Furthermore, detailed investigation is necessary to identify and quantify the factors that affect the reproductive and productive performances.
\end{abstract}

Keywords: Crossbred cattle; Ethiopia; Reproductive performance; Productive performance; Smallholder dairy farms

\section{Introduction}

The livestock sector is the source of animal protein, power for crop cultivation, means of transportation, export commodities, manure for farmland and household energy, security in times of crop failure, and means of wealth accumulation. Ethiopia has about 56.71 million cattle, 29.33 million sheep, 29.11 million goats, 1.16 million camels, and 56.87 million poultry in the country, excluding livestock populations in the non-sedentary (nomadic) areas of Afar and Somali regions [1].

Among livestock species, cattle contribute significantly to the livelihoods of farmers [2]. Despite the importance of cattle to the farming community in particular and to the national economy at large, the sector has remained underdeveloped and underutilized. Dairying is one of the livestock productions practiced almost all over the world including Ethiopia, involving a vast number of small, medium, or largesized, subsistence or market-oriented farms.

Recently, the Ethiopia livestock master plan [3] has addressed a more diverse category of the livestock systems in the country, mainly targeting the smallholder family and commercial specialized production systems [4]. Improvement in smallholder dairy production contributes to the availability of milk for public consumption and also improves the economic status of smallholder farmers. In order to maintain a long economically productive life of a cow, high reproductive efficiency and milk production are important [5]. Failure to maintain a high degree of reproductive efficiency has been associated with major economic losses in the dairy industry mainly through increase in the length of unproductive life of cows [6].

Productive and reproductive traits are crucial factors determining the profitability of dairy production. The reproductive efficiency can be assessed by several parameters which are termed as reproductive indices. The success of dairy production in general and crossbreeding programmes in particular needs to be monitored regularly by assessing the productive and reproductive performance under the existing management system [7].

Reproductive efficiency and productivity of cattle low in Ethiopia for various reasons, such as inadequate nutrition, poor genetic potential, inadequate animal health services, poor genetic potential, inadequate animal health services, poor genetic potential, inadequate animal health services, appropriate reproductive and production record keeping, access and quality of insemination, environment, diseases and other management related problems [7-13].

Most of the previous researches conducted have been for cows under relatively controlled conditions as questionnaire based crosssectional studies. Longitudinal observational studies are however, vital to overcome absence or incomplete data-recording and difficulty to get reliable data at the smallholder production [7]. Therefore, the present investigation was undertaken on crossbred cattle maintained in smallholder conditions with the objective of investigating productive and reproductive performance of smallholder dairy and associated risk factors in and around Wolaita Sodo town.

*Corresponding author: Mandefot Meaza, School of Veterinary Medicine Wolaita Sodo University, Ethiopia, Tel: +2510924053299; E-mail: meazamande@yahoo.com

Received June 15, 2017; Accepted July 22, 2017; Published July 24, 2017

Citation: Meaza M (2017) Longitudinal Study on Reproductive and Productive Performances of Smallholder Crossbred Dairy Cattle in and Around Wolaita Sodo, Snnpr, Ethiopia. J Vet Sci Technol 8: 458. doi: 10.4172/2157-7579.1000458

Copyright: ( $) 2017$ Meaza M. This is an open-access article distributed under the terms of the Creative Commons Attribution License, which permits unrestricted use, distribution, and reproduction in any medium, provided the original author and source are credited. 


\section{Materials and Methods}

\section{Study area}

The study was conducted in and around Wolaita Sodo town, Wolaita zone, Southern Nations, Nationalities and People Regional State (SNNPR), Ethiopia. The study area is located at $390 \mathrm{~km}$ south of Addis Ababa. It is situated at latitude of $8^{\circ} 50^{\circ} \mathrm{N}$ and longitude of $37^{\circ} 45^{\circ} \mathrm{E}$ with an altitude of 2025 meters above sea level. The study area has mean annual temperature of $20^{\circ} \mathrm{C}$ and receives rainfall of $450-1446$ $\mathrm{mm}[14]$. The area is characterized by bimodal rainfall pattern with the high rainy season extending from June to September and a small rainy season occurring from February to April. The mean annual rain fall of the area ranges from $450-1446 \mathrm{~mm}$ with the lowest being in low land and highest in high land [15].

\section{Study animals}

A total of 12 crossbred (Boran X Holstein Friesian) smallholder dairy farms became part of the longitudinal study. Although the exotic blood level of crossbred cows was clearly known, based on the information of owners and consulting animal health professionals, for some, the exotic blood level ranges from $50 \%$ to even higher levels. Farms having at least five dairy cows were considered in the study. The age and lactation number from two to ten years and one to eight years respectively, were considered.

\section{Study design}

At the beginning of the research questionnaire based interview and visit was conducted that was followed by two year longitudinal study. Smallholder dairy farm owners and/or attendants interviewed to generate data on the general farm conditions, cow attributes (age, parity and breed), information on breeding and $\mathrm{AI}$ and related problems. The longitudinal study was performed daily by farm attendants; once per two weeks by assistant researchers and monthly by the researcher for detailed data soundness and clinical examination of the cows considered for the study.

Longitudinal productive and reproductive performances indicators data recording, clinical examination especially during late pregnancy and postpartum period and observation of managemental problems was conducted for two years to assess reproductive indices such as age at first calving (AFC), calving to conception interval (CCI), calving interval (CI) and number of service per conception (NSC) and productive performance was measured by determining the average daily milk yield, lactation length and lactation milk yield (LMY). Among several reproductive health problems which are bottleneck are for dairy farms such as retained fetal membrane (RFM), abortion, mastitis, repeated breading and dystocia were considered.

\section{Data analysis}

Collected data were stored into Microsoft Excel spreadsheet and summarized by descriptive statistics. It was further analyzed by SPSS (version 20.0) to see the effects of different factors on the reproductive and lactation performance parameters.

\section{Results and Discussion}

\section{General farm conditions and management}

Smallholder dairy farming constitutes an important part in the dairy sector which plays a crucial role for economic development of the country as a source of food and income. The average number of dairy cows considered form each smallholder dairy farm was eight with minimum and maximum accounting to 2 and 15, respectively. Among the farms in the study, 12 were aiming for income, 2 for home use and 1 for both income and home use purposes. The study showed that all the farms were intensively managed and frequency of watering and supplement feeding was twice a day from pipe, river well and spring sources. Moreover, hygienic status of barns was good, medium and poor in 5, 6 and 4 of the farms, respectively.

Veterinary service for the farms were rendered by government veterinary clinics, private animal health professionals and in very limited cases, farm personnels render services by purchasing drug from shops. According to the study, majority of smallholder farms receive the service from government veterinary district clinics whereas lesser proportions private professionals and purchase of drugs form shops. Almost all farms (except one) had experience in vaccinating the cows against diseases such as foot and mouth disease (FMD), lumpy skin disease (LSD), anthrax, blackleg and bovine Pasteurellosis; however, it was irregular and not all types of vaccines were available yearly.

Among all the smallholder dairy farms, ten, one and four farms were using AI, bull and both services, respectively. Uniformly heat detection was done twice per day parallel with feeding and watering time but was not intentionally meant to check for estrus signs so that it is better to say that it was irregular type of heat detection. The average time between heat sign detection and insemination was 7.73 hours. Only in two smallholder farms pregnancy diagnosis was done by veterinarians or animal health workers about two months after insemination, but in the rest of the farms owners or attendants checked pregnancy through observation. However it was not plentiful information, only one smallholder had record keeping practice of their cows' reproductive information including birth date, heat sign, date of insemination and related issues.

\section{Reproductive performance}

Age at First Calving (AFC): The mean AFC was estimated to be $37.5 \pm 0.6$ months. Both farm size and calving season were not significantly correlated to AFC. The current finding is comparable with the previous studies by [16-18] who have reported $34.8 \pm 4$ months of mean AFC in Assela, $36.4 \pm 1.7$ months in Mekelle and 34.8 months in Asella, respectively. The mean AFC obtained in this study was higher than most of the reports including $18.7 \pm 3.5$ months in two towns (Bishoftu and Akaki) in central Ethiopia [19], $31.9 \pm 0.22$ months for crossbred cattle in Ziway [20] and 32.4 [21]. The prolonged AFC cows in present study compared to literature could be attributed to factors such as poor nutrition and management practices including poor heat detection at the time of mating the heifers and knowledge and perception of owners about the appropriate age for insemination of heifers. With good nutrition it is expected that heifers would exhibit fast growth and attain higher weights at relatively younger ages.

Calving Interval (CI): The current study revealed that the overall mean \pm SE calving interval $(\mathrm{CI})$ was $518.0 \pm 22.5$ days $(n=43)$. Farm size had significant influence on $\mathrm{CI}(\mathrm{P}<0.05)$, while parity and calving season had no significant influence on $\mathrm{CI}(\mathrm{P}>0.05)$ as indicated in the Table 1. Smallholder dairy farms with farm size greater than 10 dairy cattle had lower CI than smaller farm size. This may be large sized farms may have better management since they conside the dairy farm as relevant business.

This present study finding is lower than 551.82 days by [9] and $557.7 \pm 0.01$ and $556.6 \pm 0.02$ in $<50 \%$ blood level exotic crossbred cattle in rural and peri-urban areas, respectively [22]. However, this 
Citation: Meaza M (2017) Longitudinal Study on Reproductive and Productive Performances of Smallholder Crossbred Dairy Cattle in and Around Wolaita Sodo, Snnpr, Ethiopia. J Vet Sci Technol 8: 458. doi: 10.4172/2157-7579.1000458

Page 3 of 5

report is in line with the finding of [23] who reported 1.62 years for crossbred cattle in peri-urban farms; 516 days $(n=47)$ reported in the central highlands of Ethiopia [7] and 525 days at Abernosa ranch [24].

The recent finding is higher than 13.9 and 12.8 months reported for crossbred cattle in small and medium farms, respectively in Gondar city [25] and 1.31 and crossbred cattle in urban area reported by [23] in Northern Ethiopia. And also the reports on smallholder crossbred dairy farms where CI was $26.9 \pm 5.4$ (Bishoftu) and $27.0 \pm 3.7$ (Akaki) months [19] and $372.8 \pm 5.9$ days (12.4) months in Assela town [16]. The longer calving interval in this study might be related to poor heat detection, poor feeding practices and related managemental factors.

Calving to Conception Interval: CCI of $253.9 \pm 22.6$ days coincides with that of [7] who reported 253 days in a longitudinal study in central highlands of Ethiopia. On the other hand, the finding is longer than [10,26,27] who reported 201, 219 and 176 days, respectively. The result is not within the range of acceptable performance (between 80 and 115 ) for improved smallholder cows in the tropics, in order to achieve the target 13-14 months of CI [28]. Prolonged CCI may be attributed to managemental problems like nutrition, housing, efficiency of heat detection and timely insemination.

Number of Service per Conception (NSC): The overall mean \pm SE of number of services per conception (NSC) was $2.1 \pm 0.2(n=43)$. All three variables considered had no statistically significant influence on NSC $(\mathrm{P}>0.05)$. This result is within the range of previous reports which describe $2.14 \pm 0.09$ average for all crossbreds with different exotic blood level in urban and periurban [22]1.58 ( \pm 0.05) for crossbred cattle [12]; 1.9, 1.93 and 1.96 in Bishoftu, Akaki kality and kolfe keranio, respectively [29]; 2.2 as reported in eastern low land, Dire Dawa by [26] and 2.1 as reported by [27] in Addis Ababa. However, thisvalue do not reach the recommended level for crossbred cattle in the tropics.
Due to postpartum reproductive problems, service per conception, can be repeated due to poor heat detection skills, inefficiency of AI and/or poor body condition of the cows at mating. Shortage of AI input, and low semen quality might be the main problem (Tables 1 and 2).

\section{Lactation performance and feeding:}

Lactation milk yield (LMY): Only farm size had significantly $(p<0.05)$ influenced LMY. The LMY of herd size greater than 10 dairy cows had lower LMY than herd size with less than 10 dairy cows.

The overall mean LMY \pm SE was $3534.16 \pm 311 \mathrm{~kg} /$ cow. This result is analogous to $3208.56 \pm 108.8 \mathrm{Kg} /$ cow reported by [19]. However, it is greater than $2069.16 \pm 78.44$ litres [30], 1511.5 litres reported in crossbred dairy cows in North Showa zone of Ethiopia [31], 1508 litres reported in Central Highlands of Ethiopia [32] and 2333.63 litres in Zebu X Holstein-Friesian crossbred dairy cows in Jimma Town, Oromia, Ethiopia [11]. On the other hand, the present finding is lower than 4167.33 liters for crossbred cows with higher exotic blood level [22]

Daily milk yield: The mean \pm SE daily milk yield was $8.32 \pm 0.6$ liter. The present finding of average daily milk yield was in line with report of $8.52 \pm 3.04$ liters per cow [11] and 8 liters as reported by [33]. Findings of [10] who reported $11.6 \pm 3.1$ and $10.8 \pm 2.4$ liters per day/cows in Bishoftu and Akaki towns, respectively and $9.40 \pm 2.33$ litre/cow per day in Ada'a woreda by [34] were higher than our result. However, the current finding is higher than $4.73 \pm 3.2$ liters at Ezha Districts of the Gurage Zone [35].

Lactation length: The period of time from parturition (start of milking) to the time of drying off is known as Lactation length. The mean \pm SE of lactation length in the current study was $423.79 \pm 16$. Ten month is commonly accepted as a standard for lactation length

\begin{tabular}{|c|c|c|c|c|c|c|c|c|c|}
\hline \multirow[t]{2}{*}{ Variable } & \multirow[b]{2}{*}{ Freq. } & \multicolumn{2}{|c|}{$\begin{array}{l}\text { Age at first calving } \\
\text { (AFC) }\end{array}$} & \multicolumn{2}{|c|}{ Calving interval $(\mathrm{Cl})$} & \multicolumn{2}{|c|}{$\begin{array}{l}\text { Calving to conception } \\
\text { interval }(\mathrm{CCl})\end{array}$} & \multicolumn{2}{|c|}{$\begin{array}{l}\text { No. service per consumption } \\
\text { (NSC) }\end{array}$} \\
\hline & & $\mathrm{LSM} \pm \mathrm{SE}$ & $P$ value & LSM \pm SE & $P$ value & LSM \pm SE & $P$ value & LSM \pm SE & $P$ value \\
\hline \multicolumn{10}{|l|}{ Cal. seasons } \\
\hline Dry & 19 & $37.7 \pm 1.09$ & 0.615 & $500.7 \pm 141.1$ & 0.745 & $230.7 \pm 141.1$ & 0.487 & $2.2 \pm 1.4$ & 0.651 \\
\hline Short rainy & 13 & $37.5 \pm 0.89$ & & $548.7 \pm 167.2$ & & $278.7 \pm 167.2$ & & $2.0 \pm 0.8$ & \\
\hline Long rainy & 11 & $37 \pm 0.9$ & & $511.8 \pm 143.3$ & & $264.6 \pm 145.2$ & & $2.0 \pm 1.7$ & \\
\hline \multicolumn{10}{|l|}{ Parity No. } \\
\hline 1 & 9 & & & $512.9 \pm 38.4$ & 0.234 & $242.9 \pm 38.49$ & 0.280 & $2.3 \pm 0.5$ & 0.175 \\
\hline 2 & 9 & & & $636.2 \pm 71.2$ & & $366.2 \pm 71.2$ & & $2.8 \pm 0.7$ & \\
\hline 3 & 16 & & & $469.4 \pm 27.5$ & & $215.1 \pm 29.6$ & & $1.7 \pm 0.2$ & \\
\hline$\geq 4$ & 9 & & & $491.4 \pm 36.1$ & & $221.4 \pm 36.1$ & & $1.9 \pm 0.3$ & \\
\hline \multicolumn{10}{|l|}{ Farm size } \\
\hline$<10$ dairy & 26 & $38.9 \pm 0.6$ & $0.001 *$ & $500.0 \pm 26.7$ & 0.330 & $239.7 \pm 27.3$ & 0.446 & $2.0 \pm 0.2$ & 0.427 \\
\hline$>10$ cows & 17 & $35.2 \pm 0.8$ & & $545.5 \pm 39.8$ & & $275.5 \pm 39.8$ & & $2.3 \pm 0.4$ & \\
\hline Over all & 43 & $37.5 \pm 0.6$ & & $518.0 \pm 22.5$ & & $253.9 \pm 22.6$ & & $2.1 \pm 0.2$ & \\
\hline
\end{tabular}

Table 1: Least square means \pm standard error of reproductive indices crossbred smallholder cattle in and around Wolaita Sodo of SNNPR, Ethiopia.

\begin{tabular}{|c|c|c|c|c|}
\hline Variables & No. of Observations & Mean & Standard deviation & Minimum \\
\hline Lactation length (days) & 43 & 423.7 & 104.87 & 238 \\
\hline Daily milk yield (L) & 43 & 8.32 & 4.23 & 20.5 \\
\hline Lactation milk yield (L) & 43 & 3534.1 & 2039.38 \\
\hline
\end{tabular}

Table 2: Productive performance of crossbred dairy cows in smallholder dairy farms in Woaita Sodo town. 
Citation: Meaza M (2017) Longitudinal Study on Reproductive and Productive Performances of Smallholder Crossbred Dairy Cattle in and Around Wolaita Sodo, Snnpr, Ethiopia. J Vet Sci Technol 8: 458. doi: 10.4172/2157-7579.1000458

Page 4 of 5

of modern farms, but in our study it was about 14.1 months. All the independent variables included had no statistically significant influence on lactation length $(\mathrm{P}>0.05)$.

The observed result in the present study was prominently longer than reports of [33], 9.8 months [36], 10.5 months and $9.69 \pm 0.26$ months of lactation length [22]. This long lactation length probably indicates that farmers in the study area milk cows until they are quite dry. However, this milking practice has negative effect on calving interval, next season milk and productive efficiency of the cow. An extended lactation period has practical significance for the smallholder dairy farmers as it provides compensation for the usually extended calving [37]. On another hand numerous studies have documented that additional days in which cows are not pregnant beyond the optimal time post calving are costly [38]

Incidence of reproductive health problems: The overall incidence of reproductive health problems was $15 / 43(34.88 \%)$ with mastitis being the highest among the disorders accounting 8(18.6\%). In addition, other reproductive health problems encountered were RFM, abortion, dystocia and repeated breeder during the study period with $4.65,2.3$, 4.65 and $4.65 \%$, respectively.

The result of overall reproductive disorders of dairy cattle $34.88 \%$, is in line with some of the previous studies in different parts of Ethiopia including $35.5 \%$ by [39] in Wolaita Sodo Town and 33.6\% in Hawassa town by [40]. But the result is lower than $44.3 \%$, [41] in central Ethiopia and $43.07 \%$ [42] in urban and per urban areas of Hosanna, Southern Ethiopia. On the other hand the finding is greater than $18.5 \%$ reported by [43] in Asella town and 26.5\% [44] in Bedelle. Differences among the previous studies could be emanated due to study methodology and sample size, animals management and production systems and breed and other related factors.

\section{Conclusion and Recommendations}

The study area, as one of growing urban smallholder dairy production in southern Ethiopia, has actual struggle in dairy production to satisfy the ever increasing demand for milk. However, generally the observed reproductive and productive indices showed poor performances of crossbred smallholder dairy farms in the study area. Since most reproductive traits have a low heritability, it is apparent that most progress can be achieved by paying attention to management factors. Shortage of land and feeds are among the major constraints limiting dairy production. Furthermore, for better reproductive health artificial insemination management is also required.

In line with the above conclusion the following points are forwarded:

- Awareness and trainings on specific dairy farm management practices should be done to equip newly established and ongoing urban and peri-urban smallholder farms,

- Extension services should be encouraged to enhance smallholder crossbred dairy cattle production by improving animal nutrition, hygiene, animal health care practices, and other infrastructure,

- Accordingly, further detailed investigation is necessary to identify and quantify the factors that decrease the reproductive and productive performance in the study area.

\section{Acknowledgements}

This research work was conducted through the grant of Wolaita Sodo University. I want to extend my deepest gratitude to Wolaita Sodo University colleagues who had role in the process of the research.

\section{References}

1. CSA (Central Statistics Agency) (2015) Agricultural sampling survey report on livestock and livestock characteristics (private peasant holdings). Statistical Bulletin 578, Addis Ababa, Ethiopia.

2. Melaku T (2011) Oxenization versus Tractorization: Options and Constraints for Ethiopian Framing System. Int J Sustainab Agric 3: 11-20

3. Shapiro I, Gebru G, Desta S, Negassa A, Nigussie K, et al. (2015) Ethiopia livestock master plan. International Livestock Research Institute (ILRI) Project Report, Nairobi, Kenya.

4. Gizaw S, Megersa A, Muluye M, Hoekstra D, Gebremedhin B, et al. (2016) Smallholder dairy farming systems in the highlands of Ethiopia: System-specific constraints and intervention options. LIVES Working Paper 23. Nairobi, Kenya: International Livestock Research Institute (ILRI).

5. Das SM, Mgheni M, Msechu JKK, Mpiri DB (1986) Association between milk production and reproduction and reproductive efficiency in Mpwapwa cattle and their crosses. Proceedings of 13th Scientific Conference of TSAP, Arusha, Tanzania.

6. Plaizier JCB, King GJ, Dekkers JCM, Lissemore K (1998) Modeling the relationship between reproductive performance and net-revenue in dairy herds. Agric Sys 56: 305-322.

7. Lobago F, Bekana, M, Gustafsson H, Kindahl H (2007) Longitudinal observation on reproductive and lactation performances of smallholder crossbred dairy cattle in Fitche, Oromia region, central Ethiopia. Trop Anim Health Prod 39: 395-403.

8. Mulangila RCT (1997) A study of dairy cattle productivity in Tanga region, M.Sc. Thesis. Sokoine University of Agriculture, Morogoro, Tanzania.

9. Shiferaw Y, Tenhagen BA, Bekana M, Kassa T (2003) Reproductive Performance of Crossbred Dairy Cows in Different Production Systems in the Central Highlands of Ethiopia. Trop Anim Health Prod 35: 551-561.

10. Lobago F, Bekana M, Gustafsson H (2006) Reproductive performances of dairy cows in smallholder production system in Selalle, central Ethiopia. Trop Anim Health Prod 38: 333-342.

11. Belay D, Yisehak K, Janssens GPJ (2012) Productive and Reproductive Performance of Zebu X Holstein-Friesian Crossbred Dairy Cows in Jimma Town, Oromia, Ethiopia. Global Veterinaria 8: 67-72.

12. Ali T, Lemma A, Yilma T (2013) Reproductive performance of dairy cows under artificial insemination in south and northwest part of Ethiopia. Livest Res Rural Dev 25: 191

13. Tsegaye M, Gebrekidan B, Afera B (2014) Survey on Reproductive Performance of Smallholder Dairy Cows in Hawassa City, Ethiopia. J Reprod Infertility 5: 69-75.

14. WZFEMD (2011) Wolaita Zone Financial and Economic main Department Zonal Basic Socio-economic and Demographic Information November, 2011 Wolaita Sodo.

15. WZFEMD (2013) Wolaita Zone Financial and Economic main Department Zonal Basic Socio-economic and Demographic Information November 2013Wolaita Sodo.

16. Hunduma D (2012) Reproductive performance of crossbred dairy cows under smallholder condition in Ethiopia. Int J Livest Prod 3: 25-28.

17. Kumar N, Tkui K (2014) Reproductive performance of crossbred dairy cows in Mekelle, Ethiopia. Sci J Anim Sci 3: 35-40.

18. Yolyos T (2016) A study of level of reproduction of crossbred dairy cows under smallholder condition in Ethiopia. African J Dairy Farming Milk Prod 3: 149-151.

19. Genzebu D, Tamir B, Berhane G (2016) Study of Reproductive and Production Performance of Cross Breed Dairy Cattle under Smallholders Management System in Bishoftu and Akaki Towns. Int J Adv Res Biol Sci 3: 118-123.

20. Yifat D, Kelay B, Bekana M, Lobago F, Gustafsson H, et al. (2009) Study on reproductive performance of crossbred dairy cattle under smallholder conditions in and around Zeway, Ethiopia. Res Rural Dev 21: 55-56.

21. Nibret, M (2012) Study on Reproductive Performance of Crossbred Dairy Cows under Small Holder Conditions in and Around Gondar, North Western Ethiopia. J Reprod Infertility 3: 38-41.

22. Abera M (2016) Reproductive and Productive Performances of Crossbred 
Citation: Meaza M (2017) Longitudinal Study on Reproductive and Productive Performances of Smallholder Crossbred Dairy Cattle in and Around Wolaita Sodo, Snnpr, Ethiopia. J Vet Sci Technol 8: 458. doi: 10.4172/2157-7579.1000458

Page 5 of 5

and Indigenous Dairy Cattle under Rural, peri-urban and Urban Dairy Farming Systems in West Shoa Zone, Oromia, Ethiopia. MSc. Thesis, Jimma University, College of agriculture and veterinary medicine, Jimma, Ethiopia.

23. Gebrekidan TW, Zeleke MZ, Gangwar SK (2012) Reproductive and productive performance of dairy cattle in central Zone of Tigray, northern Ethiopia. Int J Adv Bio Res 2: 58-63.

24. Haile-mariam M, Banjaw K, Gebre-Meskel J, Ketema T (1993) Productivity of Boran Cattle and Their Friesian Crosses at Abernossa Ranch, Rift Valley of Ethiopia. I. Reproductive Performance and Preweaning Mortality. Trop Anim Health Prod 25: 239-248.

25. Nuraddis I, Ashebir A, Shiferaw M (2011) Assessment of reproductive performance of cross breed dairy cattle (Holstein Frisian xZebu) in Gonder Town. Global Vet 6: 56-566.

26. Mureda E, Mekuriaw Z (2007) Reproductive performance of crossbred dairy cows in Eastern Lowlands of Ethiopia. Livest Res Rural Dev 19: 11.

27. Lemma A, Kebede S (2011) The effect of mating system and herd size on reproductive performance of dairy cows in market oriented urban dairy farms in and around Addis Ababa. Rev Vet Med162: 526-530.

28. Perera O (1999) Small holder dairying in the tropics: Management of reproduction. ILRI (International Livestock Research Institute), Nairobi, Kenya.

29. Tekle Z, Guadu T, Demissie K, Mitku F, Demessie Y (2016) Assessment of Reproductive Performance of Crossbred Dairy Cattle among Dairy Farms in and Around Addis Ababa, Central Ethiopia. Global Vet 17: 358-364.

30. Kumar N, Abadi Y, Gebrekidan B, Hagos Y (2014) Productive and Reproductive Performance of Local Cows under Farmer's Management in and around Mekelle, Ethiopia. IOSR-J Agric Vet Sci 7: 21-24

31. Mulugeta A, Belayeneh A (2013) Reproductive and lactation performances of dairy cows in Chacha Town and nearby selected kebeles, North Shoa Zone, Amhara Region, Ethiopia. World J Agric Sci 1: 8-17.

32. Zelalem Y (1999) Smallholder Milk Production Systems and Processing Techniques in the Central Highlands of Ethiopia. M.Sc. Thesis. Swedish University of Agricultural Sciences, Uppsala.

33. Adebabay K (2009) Characterization of Milk Production Systems, Marketing and On- Farm Evaluation of the Effect of Feed Supplementation on Milk Yield and Composition at Bure District, Ethiopia. Msc. Thesis, Bahirdar University, Bahirdar, Ethiopia.

34. Alemayehu N, Hoekstra D, Tegegne A (2012) Smallholder dairy value chain development: The case of Ada'a woreda, Oromia Region, Ethiopia. Nairobi: ILRI.

35. Bereda A, Yilma Z, Nurfeta A (2014) Dairy Production System and Constraints in Ezha Districts of the Gurage Zone, Southern Ethiopia. Global Vet 12: 181-186.

36. Laval G, Assegid W (2002) Traditional horro cattle production in Boji district, West Wolloga, Ethiopia. Ethiopian J Anim Prod 2: 97-114.

37. Tanner JC, McCarthy NA, Omore AO (1998) Why shorten calving intervals on smallholder dairy farms in East Africa. In: Proceedings of The KARI/APSK/ ILRI/BSAS Conference on Foods Lands and Livelihoods: Setting Research Agendas for Animal Science. Nairobi, Kenya, January 27-30, 1998.

38. Groenendaal H, Galligan, DT, Mulder HA (2004) An economic spreadsheet model to determine optimal breeding and replacement decisions for dairy cattle. J Dairy Sci 87: 2146-2157.

39. Enda W, Moges Ni (2016) Major Reproductive Health Problems in Dairy Cows in Wolaita Sodo Town in Selected Farms. Eur J Biol Sci 8: 85-90.

40. Fasil N, Juta TS, Sheferaw D (2016) Major Health Challenges of Dairy Cattle in Hawassa Town SNNPRS, Ethiopia. J Vet Sci Technol 7: 1-6.

41. Hadush A, Abdella A, Regassa F (2013) The Major prepartum and postpartum reproductive problems of dairy cattle in Central Ethiopia. J Vet Med Anim Health 5: 118-123.

42. Adane H, Yisehak T, Niguse T (2014) Assessment of Major Reproductive Disorders of Dairy Cattle in urban and Peri urban area of Hosanna, Southern Ethiopia. Anim Vet Sci 2: 135-141.

43. Hunduma D (2013) The major reproductive disorders of dairy cows in and around Asella town, Central Ethiopia. J Vet Med Anim Health 5: 113-117.

44. Molalegne B, Shiv $P$ (2011) Study on major reproductive health problems in indigenous and cross breed cows in and Around Bedelle, South West Ethiopia. J Anim Vet Adv 10: 723-727. 